\title{
Investigation of the Effect of Environmental Conditions on the Rate of Exopolysaccharide Synthesis in Azotobacter vinelandii
}

\author{
By T. R. JARMAN, L. DEAVIN, S. SLOCOMBE \\ AND R. C. RIGHELATO \\ Tate and Lyle Ltd (Group Research and Development), \\ P.O. Box 68, Reading, Berkshire, RG6 $2 B X$
}

(Received 7 December 1977)

Exopolysaccharide was produced by Azotobacter vinelandii NCIB 9068 grown under a variety of environmental conditions. The rate of exopolysaccharide synthesis from sucrose in continuous culture remained within the range 5 to $14 \mathrm{mg}$-atom $\mathrm{C}$ (g cell) ${ }^{-1} \mathrm{~h}^{-1}$ for specific growth rates of 0.05 to $0.25 \mathrm{~h}^{-1}$, for rates of sucrose utilization of 16 to $105 \mathrm{mg}$-atom $\mathrm{C}$ (g cell) $)^{-1} \mathrm{~h}^{-1}$ and for a range of growth-limiting nutrients, including sucrose.

\section{INTRODUCTION}

A wide range of bacteria are known to produce copious quantities of exopolysaccharide, commonly manifest as large mucoid colonies on agar plates or highly viscous broths in submerged culture. This property is particularly common amongst plant pathogens such as Xanthomonas (Dye \& Lelliott, 1974), Erwinia (Eden-Green \& Knee, 1974) and the aerobic nitrogen-fixing bacteria Rhizobium (Jordan \& Allen, 1974), Beijerinckia (Becking, 1974) and Azotobacter (Johnstone, 1974). The exopolysaccharide can form a large proportion of the biosynthetic products of the bacteria; for instance, ratios of exopolysaccharide to cell dry weight of 3 have been reported for Azotobacter (Deavin et al., 1977) and 1 for Rhizobium meliloti (Dudman, 1964). The functions of exopolysaccharides in nature have not been established, though it has been suggested that they may protect against desiccation, phagocytosis and phage attack (Wilkinson, 1958; Sutherland, 1972) or high oxygen tension (Postgate, 1974), be involved in uptake of metal ions (Wilkinson, 1958; Sutherland, 1972), act as adhesive agents (Johnson et al., 1977) or ATP sinks (Neijssel \& Tempest, 1976) or participate in interactions between plants and bacteria (Dazzo \& Brill, 1977; Morris et al., 1977).

As part of an investigation of the physiology of exopolysaccharide production by Azotobacter vinelandii we have studied its synthesis under a range of nutritional stresses. In addition, by varying growth rate and respiration we have investigated the relationship between flux of carbohydrate into the cell and the flux through the main catabolic pathways and exopolysaccharide biosynthetic pathway. The exopolysaccharide produced by this bacterium is a partially acetylated $(1 \rightarrow 4)$-linked linear copolymer of L-mannuronic acid and D-guluronic acid (Gorin \& Spencer, 1966; Larsen \& Haug, 1971) and is thus similar to the alginates produced by certain species of brown seaweed.

\section{METHODS}

The organism, its maintenance and growth media. Azotobacter vinelandii (NCIB 9068) was maintained on growth medium I solidified with $1.5 \%(w / w)$ agar. Stock cultures were subcultured every 6 months, grown at $30{ }^{\circ} \mathrm{C}$ for $2 \mathrm{~d}$ and stored at $4{ }^{\circ} \mathrm{C}$. Working cultures were subcultured from the stock culture every 6 months and were themselves subcultured monthly. 
Two growth media were used. Medium I contained (per litre): sucrose, $20 \mathrm{~g} ; \mathrm{KH}_{2} \mathrm{PO}_{4}, 8 \mathrm{mg}_{2} \mathrm{~K}_{2} \mathrm{HPO}_{4}$, $32 \mathrm{mg} ; \mathrm{MgSO}_{4} .7 \mathrm{H}_{2} \mathrm{O}, 0.2 \mathrm{~g} ; \mathrm{NaCl}, 0.2 \mathrm{~g} ; \mathrm{CaCl}_{2} .2 \mathrm{H}_{2} \mathrm{O}, 42 \mathrm{mg} ; \mathrm{Na}_{2} \mathrm{MoO}_{4}, 1 \mathrm{mg} ; \mathrm{FeSO}_{4} .7 \mathrm{H}_{2} \mathrm{O}, 3 \mathrm{mg}$; $\mathrm{H}_{3} \mathrm{BO}_{4}, 2.9 \mathrm{mg} ; \mathrm{CoSO}_{4} .7 \mathrm{H}_{2} \mathrm{O}, 1.2 \mathrm{mg} ; \mathrm{CuSO}_{4} .5 \mathrm{H}_{2} \mathrm{O}, 0.1 \mathrm{mg} ; \mathrm{MnCl}_{2} .4 \mathrm{H}_{2} \mathrm{O}, 0.09 \mathrm{mg} ; \mathrm{ZnSO}_{4} .7 \mathrm{H}_{2} \mathrm{O}, 1.2 \mathrm{mg}$. All ingredients were autoclaved together for $1 \mathrm{~h}$ at $0.1 \mathrm{MPa}$. Medium II contained (per litre): sucrose, $40 \mathrm{~g}$; $\mathrm{KH}_{2} \mathrm{PO}_{4}, 64 \mathrm{mg} ; \mathrm{K}_{2} \mathrm{HPO}_{4}, 0.26 \mathrm{~g} ; \mathrm{MgSO}_{4} .7 \mathrm{H}_{2} \mathrm{O}, 1.6 \mathrm{~g} ; \mathrm{NaCl}, 1.6 \mathrm{~g} ; \mathrm{Na}_{2} \mathrm{MoO}_{4} .2 \mathrm{H}_{2} \mathrm{O}, 8 \mathrm{mg} ; \mathrm{CaCl}_{2} .2 \mathrm{H}_{2} \mathrm{O}$, $0.34 \mathrm{~g} ; \mathrm{FeCl}_{2} .4 \mathrm{H}_{2} \mathrm{O}, 17 \mathrm{mg} ; \mathrm{H}_{3} \mathrm{BO}_{4}, 23 \mathrm{mg} ; \mathrm{CoSO}_{4} .7 \mathrm{H}_{2} \mathrm{O}, 0.8 \mathrm{mg} ; \mathrm{MnCl}_{2} .4 \mathrm{H}_{2} \mathrm{O}, 0.72 \mathrm{mg} ; \mathrm{ZnSO}_{4} .7 \mathrm{H}_{2} \mathrm{O}$, $9.6 \mathrm{mg}$. To avoid precipitation on autoclaving, the medium was separated into two batches which were prepared as follows to give 201 of complete medium. Batch A contained sucrose, $\mathrm{KH}_{2} \mathrm{PO}_{4}$ and $\mathrm{K}_{2} \mathrm{HPO}_{4}$ in 14 , to which $\mathrm{MgSO}_{4}, \mathrm{NaCl}, \mathrm{Na}_{2} \mathrm{MoO}_{4}$ and trace elements other than $\mathrm{CaCl}_{2}$ and $\mathrm{FeCl}_{2}$ were added in 41 after autoclaving separately. Batch $\mathrm{B}$ contained $\mathrm{CaCl}_{2}$ autoclaved in $1900 \mathrm{ml}$, to which $\mathrm{FeCl}_{2}$ in 100 ml was added after filter sterilization. Medium batches $\mathrm{A}$ and $\mathrm{B}$ were added to the culture through separate pumps and tubing in the ratio $9: 1$. The combined addition rates were adjusted to give the desired dilution rate. To obtain growth limitation by the appropriate nutrient, the following modifications were made to medium II (per litre): molybdenum limitation, no $\mathrm{Na}_{2} \mathrm{MoO}_{4}$ added; phosphate limitation, $32 \mathrm{mg} \mathrm{KH}_{2} \mathrm{PO}_{4}$ and $65 \mathrm{mg} \mathrm{K}_{2} \mathrm{HPO}_{4}$; iron limitation, $1.7 \mathrm{mg} \mathrm{FeCl}{ }_{2} .4 \mathrm{H}_{2} \mathrm{O}$; carbon limitation, $8 \mathrm{~g}$ sucrose; calcium limitation, no $\mathrm{CaCl}_{2} .2 \mathrm{H}_{2} \mathrm{O}$ added; potassium limitation, $52 \mathrm{mg} \mathrm{KCl}, 57 \mathrm{mg} \mathrm{NaH} \mathrm{PO}_{4}$ and $0.215 \mathrm{~g} \mathrm{Na}_{2} \mathrm{HPO}_{4}$ added, and $\mathrm{KH}_{2} \mathrm{PO}_{4}$ and $\mathrm{K}_{2} \mathrm{HPO}_{4}$ omitted; sulphate limitation, $40 \mathrm{mg} \mathrm{MgSO}_{4} .7 \mathrm{H}_{2} \mathrm{O}$ and $1 \cdot 32 \mathrm{~g} \mathrm{MgCl}_{2} .6 \mathrm{H}_{2} \mathrm{O}$.

Continuous culture apparatus and conditions. The organisms were continuously cultured in a mechanically stirred 1 litre culture vessel attached to a type 1/1000 laboratory fermentation module (L.H. Engineering, Stoke Poges, Buckinghamshire). In certain experiments a draught tube was inserted into the vessel, but in others, as indicated, this was replaced by four baffles $(1 \times 13 \mathrm{~cm})$ fitted symmetrically around the perimeter of the vessel. The fermentation temperature was $30^{\circ} \mathrm{C}$. The $\mathrm{pH}$ was maintained at $7 \cdot 4( \pm 0 \cdot 1)$ by automatic addition of $1 \mathrm{~m}-\mathrm{NaOH}$. Foaming was controlled by addition, as necessary, of silicone antifoaming agent $(\mathrm{BDH})$. The rate of air flow into the culture and impeller speed were varied as indicated. Oxygen uptake and carbon dioxide evolution were monitored continuously with a paramagnetic oxygen analyser (type OA 184, Taylor Servomex, Crowborough, TN6 3DV, Sussex) and an infrared gas analyser (model SB2, Grubb Parsons, Walkergate, Newcastle NE6 2YB). Following a change in conditions a steady state was considered to exist when $A_{540}$ and oxygen uptake had remained constant for at least three residence times. Growth limitation by a medium constituent was demonstrated by (i) obtaining an increase of at least $10 \%$ in $A_{540}$ on increasing the concentration of a nutrient supplied to the culture and (ii) obtaining a steady state of higher cell mass using unmodified medium II as shown in Table 1. Oxygen limitation was obtained by decreasing the impeller speed and thus the rate of gas transfer into the sample. Nitrogen limitation was obtained by supplying the culture with argon containing oxygen $\left(20 \%\right.$, v/v) at $950 \mathrm{ml} \mathrm{min}{ }^{-1}$ and air at $50 \mathrm{ml} \mathrm{min}^{-1}$.

Cell dry weight determination. A mixture of culture $(40 \mathrm{ml}), 5 \mathrm{M}-\mathrm{NaCl}(0.8 \mathrm{ml})$ and $0.5 \mathrm{M}-\mathrm{Na}_{4}$ EDTA $(0.8 \mathrm{ml})$ was centrifuged at $24000 \mathrm{~g}$ for $40 \mathrm{~min}$. The supernatant obtained was decanted, and the sediment was resuspended in distilled water and centrifuged at $24000 \mathrm{~g}$ for $20 \mathrm{~min}$. The final sediment was transferred to a preweighed porcelain dish and dried to constant weight at $105^{\circ} \mathrm{C}$.

Polysaccharide determination. The supernatant $(25 \mathrm{ml})$ obtained from the first centrifugation described above was added to propan-2-ol $(75 \mathrm{ml})$ and the mixture was shaken vigorously. After $10 \mathrm{~min}$, the precipitate obtained was filtered on to a predried and preweighed Whatman GF/A filter disc and washed with $100 \mathrm{ml}$ of propan-2-ol/water $(3: 1, \mathrm{v} / \mathrm{v})$. The filter disc plus precipitate was dried under vacuum at $45^{\circ} \mathrm{C}$ for $24 \mathrm{~h}$, reweighed and the concentration of polysaccharide in the culture broth was calculated.

Poly-3-hydroxybutyrate was determined by the method of Law \& Slepecky (1961).

Sucrose was determined as its trimethylsilylether derivative by gas-liquid chromatography using trehalose as an internal standard (Sweeley et al., 1963).

\section{RESULTS}

\section{Variation of growth-limiting nutrient}

Nutrient limitations on growth in the chemostat were demonstrated as shown in Table 1. Exopolysaccharide was produced under all limitations tested (Table 2). With the exception of oxygen-limited conditions, there was little or no poly-3-hydroxybutyrate (PHB) produced and the rate of exopolysaccharide synthesis $\left(q_{\mathrm{ps}}\right)$ was between 5.0 and $10.5 \mathrm{mg}$-atom $\mathrm{C}$ $(\mathrm{g} \text { cell })^{-1} \mathrm{~h}^{-1}$. Oxygen limitation resulted in a significantly lower $q_{\mathrm{ps}}$ when based on whole cell mass, but microscopic examination showed that much of the cell mass was poly-3hydroxybutyrate. The $q_{\mathrm{ps}}$ based on active biomass would have been considerably higher. When sucrose, the carbon and energy source, limited growth, exopolysaccharide was produced at a rate similar to that obtained with most other limitations. Under this condition the 
Table 1. Demonstration of nutrient limitations

\begin{tabular}{|c|c|c|c|}
\hline $\begin{array}{l}\text { Limiting } \\
\text { nutrient }\end{array}$ & $\begin{array}{c}A_{540} \text { before } \\
\text { limitation } \\
\text { test* }\end{array}$ & Change in conditions for limitation test & $\begin{array}{l}A_{540} \text { after change in } \\
\text { conditions* } \dagger\end{array}$ \\
\hline $\mathrm{MoO}_{4}{ }^{2-}$ & 0.056 & $\begin{array}{l}\text { Inflowing medium changed to complete } \\
\text { medium II }\end{array}$ & $\begin{array}{l}0.071 \quad(7 \mathrm{~h}) \\
0.18 \quad(18 \mathrm{~h})\end{array}$ \\
\hline $\mathrm{PO}_{4}{ }^{3-}$ & $0 \cdot 17$ & $\begin{array}{l}\text { Inflowing medium changed to complete } \\
\text { medium II }\end{array}$ & $0 \cdot 34(24 \mathrm{~h})$ \\
\hline $\mathrm{Fe}^{2+}$ & $0 \cdot 105$ & $\begin{array}{l}\mathrm{FeCl}_{2} .4 \mathrm{H}_{2} \mathrm{O} \text { concn in inflowing medium } \\
\text { increased from } 1.7 \text { to } 5.2{\mathrm{mg} 1^{-1}}^{\text {inces }}\end{array}$ & $0.18 \quad(6 \mathrm{~h})$ \\
\hline $\mathrm{C}$ (sucrose) & $0 \cdot 117$ & $\begin{array}{l}\text { Inflowing medium changed to complete } \\
\text { medium II }\end{array}$ & $\begin{array}{l}0 \cdot 163(17 \mathrm{~h}) \\
0 \cdot 245(24 \mathrm{~h})\end{array}$ \\
\hline $\mathrm{N}\left(\mathrm{N}_{2}\right)$ & $0 \cdot 20$ & $\begin{array}{l}\text { Air in } \mathrm{Ar} / \mathrm{O}_{2} / \text { air mixtures increased from } \\
5 \text { to } 10 \%\end{array}$ & $0.26 \quad(7 \mathrm{~h})$ \\
\hline $\mathrm{Ca}^{2+}$ & 0.088 & $\begin{array}{l}\text { Inflowing medium changed to one con- } \\
\text { taining } \mathrm{CaCl}_{2} \cdot 2 \mathrm{H}_{2} \mathrm{O} \text { at } 4 \mathrm{mg} \mathrm{l}^{-1}\end{array}$ & $0.26(23 \mathrm{~h})$ \\
\hline $\mathrm{SO}_{4}{ }^{2-}$ & $0 \cdot 11$ & $\begin{array}{l}\text { Inflowing medium changed to complete } \\
\text { medium II }\end{array}$ & $0 \cdot 27 \quad(24 \mathrm{~h})$ \\
\hline $\mathrm{O}_{2}$ & $0 \cdot 14$ & $\begin{array}{l}\text { Impeller speed increased from } 400 \text { to } 600 \\
\text { rev. } \text { min }^{-1}\end{array}$ & $0.58 \quad(24 \mathrm{~h})$ \\
\hline
\end{tabular}

Table 2. Exopolysaccharide production under a variety of
nutrient limitations

Culture conditions were as described in Methods. The fermentation vessel was fitted with baffles instead of a draught tube. Growth medium II was used with the stated variations made in order to obtain the desired growth limitation. Cultures grown on unmodified medium II were phosphatelimited and had a steady state dry cell mass of $4 \mathrm{~g} \mathrm{l}^{-1}$. Respiration rate, $q_{\mathrm{CO}_{2}}$ was maintained within the range 15 to $30 \mathrm{mmol} \mathrm{CO}_{2}(\mathrm{~g} \mathrm{cell})^{-1} \mathrm{~h}^{-1}$ [except in the $\mathrm{O}_{2}$-limited condition where it was $8 \mathrm{mmol}$ $\mathrm{CO}_{2}(\mathrm{~g} \text { cell })^{-1} \mathrm{~h}^{-1}$ ] by adjusting the fermenter impeller speed. The gas flow into the culture was 11 $\min ^{-1}$; the dilution rate was $0 \cdot 15 \mathrm{~h}^{-1}$.

$\begin{array}{lcc}\begin{array}{c}\text { Limiting } \\ \text { nutrient }\end{array} & \begin{array}{c}\text { Cell mass } \\ \left(\mathrm{g} \mathrm{l}^{-1}\right)\end{array} & \begin{array}{c}\text { Polysaccharide produced } \\ \text { [mg-atom C }(\mathrm{g} \text { cell })^{-1} \mathrm{~h}^{-1} \text { ] }\end{array} \\ \mathrm{MoO}_{4}{ }^{2-} & 1 \cdot 1 & 10 \cdot 5 \\ \mathrm{PO}_{4}{ }^{3-} & 1 \cdot 9 & 8 \cdot 9 \\ \mathrm{Fe}^{2+} & 1 \cdot 4 & 8 \cdot 1 \\ \mathrm{C}(\text { sucrose }) & 1 \cdot 3 & 7 \cdot 7 \\ \mathrm{~N}^{\left(\mathrm{N}_{2}\right)} & 1 \cdot 5 & 6 \cdot 8 \\ \mathrm{Ca}^{2+} & 1 \cdot 2 & 6 \cdot 2 \\ \mathrm{SO}_{4}{ }^{2-} & 1 \cdot 7 & 7 \cdot 8 \\ \mathrm{~K}^{+} & 1 \cdot 9 & 5 \cdot 0 \\ \mathrm{O}_{2} & 1 \cdot 2 & 1 \cdot 9\end{array}$

bacteria might have been expected to make the most efficient use possible of their available carbon and energy substrate.

\section{Variation of dilution rate}

The relationship between $q_{\mathrm{ps}}$ and the specific growth rate $(\mu)$ of $A$. vinelandii was investigated in continuous culture under phosphate-limited conditions. Cell mass was constant at dilution rates between $0 \cdot 15$ and $0.25 \mathrm{~h}^{-1}$ (Table 3 ) but increased at lower dilution rates due to intracellular accumulation of poly-3-hydroxybutyrate. In the dilution rate range 0.05 to $0.25 \mathrm{~h}^{-1}, q_{\mathrm{ps}}$ was between 10.6 and $14 \mathrm{mg}$-atom $\mathrm{C}$ (g cell minus $\left.\mathrm{g} \mathrm{PHB}\right)^{-1} \mathrm{~h}^{-1}$ being largely independent of specific growth rate. The rate of sucrose utilization $\left(q_{\mathrm{s}}\right)$ varied from 35 to 98 mg-atom C ( $\mathrm{g}$ cell minus $\mathrm{g} \mathrm{PHB})^{-1} \mathrm{~h}^{-1}$ over the same range of growth rates and was determined mainly by the respiration rate, $q_{\mathrm{Co}_{2}}$. In Table 3 , the partition of carbon between cell synthesis, respiration and exopolysaccharide synthesis is shown. 

Table 3. Fate of carbon assimilated by A. vinelandii as a function
of dilution rate in phosphate-limited culture

Continuous culture conditions were as described in Methods. Growth medium I was used. The impeller speed was $700 \mathrm{rev} . \mathrm{min}^{-1}$, the air flow was $1.21 \mathrm{~min}^{-1}$ and a draught tube was inserted into the fermentation vessel. For calculation of $\mathrm{mg}$-atom $\mathrm{C}$ of exopolysaccharide, the carbon content of this partially acetylated sodium polyuronide was taken as $37 \%$.

Fate of carbon assimilated

$\begin{array}{ccccccc}\begin{array}{c}D \\ \left(\mathrm{~h}^{-1}\right)\end{array} & \begin{array}{c}\text { Cell mass } \\ \left(\mathrm{g} \mathrm{l}^{-1}\right)\end{array} & \begin{array}{c}\text { Cellular PHB } \\ \left(\mathrm{g} \mathrm{l}^{-1}\right)\end{array} & \begin{array}{c}\text { Sucrose } \\ \text { used }\end{array} & \begin{array}{c}\text { Cell mass } \\ \text { produced }\end{array} & \begin{array}{c}\mathrm{CO}_{2} \\ \text { produced }\end{array} & \begin{array}{c}\text { Exopolysaccharide } \\ \text { produced }\end{array} \\ 0.05 & 1 \cdot 37 & 0.86 & 49 & 5 \cdot 8 & 35 & 10 \cdot 6 \\ 0 \cdot 10 & 0.69 & 0.07 & 42 & 4 \cdot 7 & 23 & 11 \cdot 5 \\ 0 \cdot 15 & 0.44 & 0.01 & 56 & 6 \cdot 3 & 33 & 14 \\ 0.20 & 0.43 & <0.01 & 98 & 8 \cdot 4 & & 13 \\ 0.25 & 0.45 & <0.01 & 35 & 10.5 & 13 & 13 \cdot 3\end{array}$

Table 4. Sucrose use and exopolysaccharide production as a function of respiration rate in phosphate-limited culture

Culture conditions were as described in Methods. The dilution rate was $0 \cdot 15 \mathrm{~h}^{-1}$, the fermentation vessel was fitted with a draught tube and the air flow was $1.21 \mathrm{~min}^{-1}$. Growth medium I was used. Cellular poly-3-hydroxybutyrate content was less than $5 \%$ of the cell concentration. For calculation of mg-atom $\mathrm{C}$ of exopolysaccharide, the carbon content of this partially acetylated sodium polyuronide was taken as $37 \%$.

$\begin{array}{cccccc}\begin{array}{c}\text { Impeller } \\ \begin{array}{c}\text { speed } \\ (\text { rev. min }\end{array}\end{array} & \begin{array}{c}\text { Cell mass } \\ \left(\mathrm{g} \mathrm{l}^{-1}\right)\end{array} & \overbrace{\begin{array}{c}\text { Sucrose } \\ \text { used }\end{array}} & \begin{array}{c}\text { Cell mass } \\ \text { produced }\end{array} & \begin{array}{c}\mathrm{CO}_{2} \\ \text { produced }\end{array} & \begin{array}{c}\text { Exopolysaccharide } \\ \text { produced }\end{array} \\ 400 & 0 \cdot 55 & 16 & 6 \cdot 3 & 6 \cdot 4 & 6 \cdot 4 \\ 500 & 0 \cdot 42 & 34 & 6 \cdot 3 & 12 & 6 \cdot 9 \\ 600 & 0 \cdot 44 & 40 & 6 \cdot 3 & 28 & 11 \cdot 6 \\ 700 & 0 \cdot 44 & 56 & 6 \cdot 3 & 33 & 12 \cdot 1 \\ 870 & 0 \cdot 49 & 105 & 6 \cdot 3 & 71 & 8 \cdot 4\end{array}$

\section{Variation of respiration rate}

Further information on the relationship between the flux of hexose entering the exopolysaccharide biosynthetic pathway and central metabolic pathways was sought by investigating exopolysaccharide synthesis at a range of $q_{\mathrm{CO}_{2}}$ values with phosphate-limited growth conditions. $q_{\mathrm{CO}_{2}}$ was manipulated by adjusting the fermenter impeller speed and thereby altering the rate of oxygen transfer. As reported previously (Dalton \& Postgate, 1969), $q_{\mathrm{CO}_{2}}$ increased with increased oxygen availability. Cell mass was essentially independent of respiration rate. $q_{\mathrm{ps}}$ varied less than twofold [from 6.4 to $12 \cdot 1 \mathrm{mg}$-atom C (g cell) ${ }^{-1} \mathrm{~h}^{-1}$ ] for a tenfold increase in $q_{\mathrm{CO}_{2}}$ (Table 4). $q_{\mathrm{s}}$ increased sixfold over this $q_{\mathrm{CO}_{2}}$ range. These findings indicate that the flux of hexoses into the exopolysaccharide biosynthetic pathway is relatively independent of the flux of substrate into the cell and that of hexoses into the central metabolic pathways.

\section{DISCUSSION}

Batch-culture studies on Escherichia coli and Klebsiella aerogenes (Duguid \& Wilkinson, 1953; Wilkinson, Duguid \& Edmunds, 1954) and subsequent continuous culture studies on K. aerogenes (Neijssel \& Tempest, 1975) and a Pseudomonas sp. (Williams, 1975) indicated that exopolysaccharide production occurred under conditions where excess carbohydrate was present, growth being limited by a nutrient other than the carbon and energy source. 
In the continuous culture studies, the highest rates of exopolysaccharide synthesis were observed during nitrogen-limited growth. It was suggested that in $K$. aerogenes exopolysaccharide was an 'overflow metabolite', its biosynthesis possibly functioning as a 'slip reaction', effecting the hydrolysis and turnover of ATP (Neijssel \& Tempest, 1975, 1976). We have studied exopolysaccharide synthesis by a strain of $A$. vinelandii which excretes partially acetylated alginic acid (Gorin \& Spencer, 1966). Most species of Azotobacter and other $\mathrm{N}_{2}$-fixing aerobes accumulate copious quantities of extracellular polysaccharides. The function of these polymers is not known and strains that have lost the ability to synthesize them are viable under laboratory conditions (Sutherland, 1972). The organisms used in this study synthesized substantial quantities of alginic acid at similar rates under a wide range of conditions. Polysaccharide production under carbon (sucrose) limitation at rates similar to those found for other limiting substrates argues against an 'overflow' mechanism of the type described by Holme (1957) and Neijssel \& Tempest (1975) operating in this instance. Production of acetylated alginic acid is also known to occur under carbon (glucose) limitation in mucoid strains of Pseudomonas aeruginosa (F. A. Mian, personal communication). In experiments in which the relative rates of flux of carbon for cell biosynthesis, respiration and polysaccharide production were varied between wide limits, the absolute rate of exopolysaccharide synthesis was more or less constant. No inference can be made from these observations on the control system by which the constant rate is achieved. The biosynthetic route to exopolysaccharide diverges from the main catabolic pathways at the hexose phosphate level (Pindar \& Bucke, 1974). As mannosephosphate isomerase provides mannose 6-phosphate for alginate synthesis some control might be expected at that level. It has been suggested that competition for polyisoprenoid cofactor between exopolysaccharide synthesis and cell wall synthesis might exist (Sutherland, 1977). The independence of rate of exopolysaccharide synthesis and specific growth rate in $A$. vinelandii is not consistent with such competition.

Our observation that exopolysaccharide production in $A$. vinelandii is unaffected by most environmental conditions was considered surprising, but re-examination of other reports of polysaccharide synthesis suggests that this might not be uncommon. Reported data indicate that the specific rate of exopolysaccharide synthesis in nitrogen-limited continuous cultures of Xanthomonas campestris (Silman \& Rogovin, 1972) and of Pseudomonas sp. (Williams, 1975) varied little for specific growth rates of 0.05 to $0.2 \mathrm{~h}^{-1}$ and 0.025 to $0.25 \mathrm{~h}^{-1}$, respectively (Deavin et al., 1977). Although the physiological significance of these polymers is obscure, the diversion of large proportions of the assimilated carbohydrate into exopolysaccharide in a variety of physiological conditions and the widespread occurrence of exopolysaccharide synthesis in certain groups of bacteria suggest a major role in vivo.

\section{REFERENCES}

BeCKING, J. H. (1974). Beijerinckia. In Bergey's Manual of Determinative Bacteriology, 8th edn, pp. 256-260. Edited by R. E. Buchanan \& N. E. Gibbons. Baltimore: Williams \& Wilkins.

Dalton, H. \& Postgate, J. R. (1969). Effect of oxygen on growth of Azotobacter chroococcum in batch and continuous culture. Journal of General Microbiology 54, 463-473.

Dazzo, F. B. \& BRILl, W. J. (1977). Receptor site on clover and alfalfa roots for Rhizobium. Applied and Environmental Microbiology 33, 132136.

Deavin, L., Jarman, T. R., Lawson, C. J., RigheLATO, R. C. \& Slocombe, S. (1977). The production of alginic acid by Azotobacter vinelandii in batch and continuous culture. In Extracellular Microbial
Polysaccharides, pp. 14-26. Edited by P. A. Sandford \& A. Laskin. Washington: American Chemical Society.

DudmaN, W. F. (1964). Growth and extracellular polysaccharide production by Rhizobium meliloti in defined medium. Journal of Bacteriology 88, 640-645.

Duguid, J. P. \& Wilkinson, J. F. (1953). The influence of cultural conditions on polysaccharide production by Aerobacter aerogenes. Journal of General Microbiology 9, 174-189.

Dye, D. W. \& LelliotT, R. A. (1974). Xanthomonas. In Bergey's Manual of Determinative Bacteriology, 8th edn, pp. 243-249. Edited by R. E. Buchanan \& N. E. Gibbons. Baltimore: Williams \& Wilkins. 
Eden-Green, S. J. \& KNeE, M. (1974). Bacterial polysaccharide and sorbitol in fireblight exudate. Journal of General Microbiology 81, 509-512.

Gorin, P. A. J. \& SPENCER, J. F. T. (1966). Exocellular alginic acid from Azotobacter vinelandii. Canadian Journal of Chemistry 44, 993-998.

Holme, T. (1957). Continuous culture studies on glycogen synthesis in Escherichia coli B. Acta chemica scandinavica 11, 763-775.

JORDAN, D. C. \& AlLEN, O. N. (1974). Rhizobiaceae. In Bergey's Manual of Determinative Bacteriology, 8th edn, pp. 261-264. Edited by R. E. Buchanan \& N. E. Gibbons. Baltimore: Williams \& Wilkins.

Johnson, M. C., Bazzola, J. J., Schechmeister, L. L. \& ShklaIR, I. L. (1977). Biochemical study of the relationship of extracellular glucan to adherence and cariogenicity in Streptococcus mutans and an extracellular polysaccharide mutant. Journal of Bacteriology 129, 351-357.

Johnstone, D. B. (1974). Azotobacter. In Bergey's Manual of Determinative Bacteriology, 8th edn, pp. 254-255. Edited by R. E. Buchanan \& N. E. Gibbons. Baltimore: Williams \& Wilkins.

LARSEN, B. \& HAUG, A. (1971). Biosynthesis of alginate. I. Composition and structure of alginate produced by Azotobacter vinelandii. Carbohydrate Research 17, 287-296.

LAW, J. H. \& Slepecky, R. A. (1961). Assay of poly- $\beta$-hydroxybutyric acid. Journal of Bacteriology 82, 33-36.

Morris, E. R., Rees, D. A., Young, G., WalkiNSHAW, M. D. \& DARKE, A. (1977). Order-disorder transition for a bacterial polysaccharide in solution: a role for polysaccharide conformation in recognition between Xanthomonas pathogen and its host. Journal of Molecular Biology 110, 1-16.

NeiJssel, O. M. \& Tempest, D. W. (1975). The regulation of carbohydrate metabolism in Klebsiella aerogenes NCTC 418 organisms growing in chemostat culture. Archives of Microbiology 106, 251-259.
Neisssel, O. M. \& Tempest, D. W. (1976). Bioenergetic aspects of aerobic growth of Klebsiella aerogenes NCTC 418 in carbon-limited and carbonsufficient chemostat culture. Archives of Microbiology 107, 215-221.

Pindar, D. \& Bucke, C. (1974). The biosynthesis of alginic acid by Azotobacter vinelandii. Biochemical Journal 152, 617-622.

Postgate, J. R. (1974). Evolution within nitrogenfixing systems. Symposia of the Society for General Microbiology 24, 263-292.

Silman, R. W. \& Rogovin, P. (1972). Continuous fermentation to produce xanthan biopolymer: effect of dilution rate. Biotechnology and Bioengineering 14, 23-31.

Sutherland, I. W. (1972). Bacterial exopolysaccharides. Advances in Microbial Physiology 8 , 143-213.

Sutherland, I. W. (1977). Microbial exopolysaccharide synthesis. In Extracellular Microbial Polysaccharides, pp. 40-57. Edited by P. A. Sandford \& A. Laskin. Washington: American Chemical Society.

Sweeley, C. C., Bentley, R., Makita, M. \& Wells, W. W. (1963). Gas-liquid chromatography of trimethylsilyl derivatives of sugars and related substances. Journal of the American Chemical Society 85, 2497-2507.

Wilkinson, J. F. (1958). The exocellular polysaccharides of bacteria. Bacteriological Reviews 22, 46-73.

Wilkinson, J. F., Duguid, J. P. \& Edmunds, P. N. (1954). The distribution of polysaccharide production in Aerobacter and Escherichia strains and its relation to antigenic character. Journal of General Microbiology 11, 59-72.

Williams, A. G. (1975). Extracellular polysaccharide production by a Gram-negative bacterial isolate. Ph.D. thesis, University of Wales. 